Área Abierta. Revista de comunicación

audiovisual y publicitaria

ISSN: 1578-8393 / ISSNe: 1578-8393

\title{
Sumergirse en el infierno. El hijo de Saúl y la crisis de la representación de la imagen
}

\author{
Elios Mendieta Rodríguez ${ }^{1}$
}

Recibido: 18 de diciembre de 2017 / Aceptado: 1 de marzo de 2018

Resumen. Las imágenes de El hijo de Saúl volvieron a colocar en el centro del debate la gran polémica sobre lo representable y no representable cuando se filma el Holocausto. El objetivo de este artículo es explicar la razón por la que la película de Lászlo Nemes volvió a reabrir una crisis que parecía ya terminada, debido a lo novedoso de su planteamiento ético y estético. Por tanto, este texto profundiza en las dos versiones enfrentadas que han capitalizado esta controversia a lo largo de la historia - con Lanzmann y Didi-Huberman a la cabeza de cada una, respectivamente - para pasar a analizar el citado filme húngaro y demostrar la originalidad de su apuesta cinematográfica: su imagen claustrofóbica, el punto de vista único centrado en el protagonista, la inmersión sensorial en el infierno, la importancia de lo sonoro o su respeto por lo que sucedió como sus puntos fuertes.

Palabras clave: Representación, imagen, El Hijo de Saúl, László Nemes, Holocausto; crisis

\section{[en] Immerse Youself in Hell. The Son of Saul and the Crisis of the Representation of the Image}

\begin{abstract}
The images of Saul's Son brought back to the centre of the debate the great controversy about what is representable and unrepresentable when the Holocaust is filmed. The purpose of this article is to explain why the film by László Nemes reopened a crisis that seemed to be finished, due to the novelty of its ethical and aesthetic approach. So, this text delves into the two conflicting versions that have capitalized this controversy throughout history —with Lanzmann and Didi-Huberman at the head of each one, respectively - in order to analyze the mentioned hungarian film and demonstrate the originality of its cinematographic bet: his claustrophobic image, the unique viewpoint centralized on the protagonist, the sensorial immersion in hell, the importance of sound or his respect for what happened as his strong points.
\end{abstract}

Keywords: Representation; Image; Saul's Son, László Nemes; Holocaust; Crisis

Sumario. 1. Introducción 2. Repaso histórico de la controversia 3. El hijo de Saúl: un monstruo necesario 4. Conclusiones 5. Bibliografía 6. Filmografía imprescindible

Cómo citar: Mendieta Rodríguez, E. (2018). Sumergirse en el infierno. El hijo de Saúl y la crisis de la representación de la imagen. Área Abierta. Revista de comunicación audiovisual y publicitaria, 18 (2), 261-275. http://dx.doi.org/10.5209/ARAB.58412

1 Universidad Complutense de Madrid (España)

E-mail: eliosmr@gmail.com 


\section{Introducción}

La representación del Holocausto ha sido - y continúa siendo - uno de los mayores desafíos para los cineastas. El estreno de El hijo de Saúl (Saul fia, László Nemes, 2015) supuso la reapertura de una crisis que parecía ya anquilosada y que había persistido, prácticamente, desde que los primeros directores se atrevieron a hacer cine del horror vivido en los campos de exterminio nazis, donde fallecieron más de seis millones de judíos. Esta crisis la protagonizaban dos bloques de intelectuales, y se había cimentado en torno a la forma en que se representaba el horror en la ficción fílmica. Por una parte, se encontraban aquellos que reclamaban un límite al mostrar la Shoah, pues esta había sido tan catastrófica, salvaje e inimaginable, que ninguna imagen podía acercarse mínimamente a contar esa historia, por lo que las fotografías de archivo estaban vetadas y el testimonio oral de los supervivientes era el único camino viable para contar esta tragedia. Por otra parte, estaban los que defendían que el Holocausto, como cualquier fenómeno que ha tenido lugar, es, en sí mismo, representable, y que existe un lenguaje capaz de representar cualquier hecho, y es el que concierne al régimen estético del cine. La pregunta que ha suscitado este debate parece evidente: $i$ se prefiere un ascetismo visual en el que se omita cualquier atisbo de invención y se privilegie la palabra o son la ficción y la fuerza de las imágenes elementos imprescindibles para, también, tratar de comprender la barbarie?

El principal defensor de la vía de la irrepresentabilidad fue Claude Lanzmann, mientras que autores como Jorge Semprún, Jacques Rancière y, especialmente, Georges Didi-Huberman, refutaron constantemente las ideas del director de la revista Les Temps Modernes. Estos últimos consideraban que las imágenes de archivo que se conservaban de los campos de concentración eran imprescindibles para intentar comprender qué pasó en Auschwitz y en los demás campos de concentración, y que la ficción era una vía muy digna para acercarse al horror, siempre que esta discurriese por unos cauces éticos. El debate había empezado, prácticamente, con el inicio de la década de los cincuenta, pero se volvió recurrente tras el estreno de Shoah (1985), el documental de más de nueve horas de Lanzmann, — considerado con justicia como una de las grandes piezas cinematográficas del Holocausto-y, especialmente, tras la publicación de Imágenes pese a todo (Images malgré tout, 2003), un ensayo en el que Didi-Huberman analiza cuatro fotografías tomadas por un miembro del sonderkommando ${ }^{2}$ en Auschwitz-Birkenau. Aunque en los últimos años la crisis de la representación de la imagen parecía ya superada, El hijo de Saúl resucitó la polémica.

Pero existe un hecho por el que la ópera prima de Nemes supuso un verdadero hito en este debate: por primera vez, un filme consiguió poner de acuerdo a ambas partes,

2 Primo Levi definió el término sonderkommando en Los hundidos y los salvados, la tercera parte de su Trilogía de Auschwitz: "Con esa denominación convenientemente vaga de Escuadra Especial nombraban las SS al grupo de prisioneros a quienes les era confiado el trabajo de los crematorios. A ellos les correspondía imponer el orden a los recién llegados (con frecuencia totalmente ignorantes del destino que les esperaba) que debían ir a las cámaras de gas; sacar de las cámaras de gas los cadáveres; quitarles de los mandíbulas los dientes de oro; cortar el pelo a las mujeres; separar y clasificar las ropas, los zapatos, el contenido de las maletas; llevar los cuerpos a los crematorios y vigilar el funcionamiento de los hornos; sacar las cenizas y hacerlas desaparecer. La Escuadra Especial de Auschwitz contó, según los periodos, con una cantidad de integrantes entre setecientos y mil” (Levi, 2010:510). 
siempre enfrentadas, en cuanto a lo beneficioso de su planteamiento ético y estético. Aunque cada una de las dos partes esgrimió razones diferentes, ambas concluyeron en que el filme era muy válido en su modo de representar la imagen de la Shoah. Por tanto, el objetivo del presente artículo es demostrar, mediante el análisis de la misma, por qué El hijo de Saúl es una película de un planteamiento formal tan original, que ha sido capaz de volver a poner en el centro del debate la controversia sobre los límites de lo que se puede representar y lo que no, y explicar los mecanismos éticos y estéticos de los que se valió Nemes para construir una propuesta fílmica tan novedosa que fue capaz de reabrir una crisis que parecía ya enterrada y que, a la vez, cosechó halagos por su modo de representar la imagen por parte de ambos contendientes en el debate. No obstante, es imprescindible profundizar, de manera previa, en la historia de la polémica.

\section{Repaso histórico a la controversia}

Con la liberación de los supervivientes que quedaban en los campos de exterminio y el fin de la Segunda Guerra Mundial llegaba el momento de tratar de comprender, de afrontar la interpretación del sentido del horror, y de que comenzase a tomar cuerpo la percepción del Holocausto. Simbolizado en Auschwitz, que actúa como una poderosa sinécdoque, la Shoah y su representación se convirtió en "una de las áreas de reflexión histórico-filosóficas más importantes y fecundas del pensamiento contemporáneo" (Fernández López, 2006: 1). Fue Theodor Adorno el primero en tomar la palabra en esta necesidad de hallar respuesta a la irracionalidad destructiva de los nazis en su ensayo Cultural Criticism and Society, escrito en 1949 y reimpreso posteriormente en el volumen Prisms, y donde aseguró que escribir poesía después de Auschwitz era "un acto de barbarie" (Sáez de Urabaín, 2015: 236). La prescripción del filósofo de la Escuela de Frankfurt ha sido mal interpretada y leída como una socorrida reducción aforística, cuando su dictamen pedía que el arte fuese consciente, en su concepción, del mal acaecido durante el genocidio judío:

Adorno insiste en la idea de que una cultura resucitada tras Auschwitz es una farsa, lo cual no le impide afirmar que un mundo que ha superado la prueba del genocidio, aunque solo sea porque ha sobrevivido físicamente, no puede prescindir del arte, un arte, eso sí, ya diferente, obligado al memento de los caídos y a hacerse eco del horror (López Fernández, 2006: 1).

Tras Adorno, la primera gran crítica al modo que se representaba la ficción del Holocausto llegó por medio del director Jacques Rivette, que criticó el travelling filmado por Gillo Pontecorvo en su filme Kapo (Kapò, 1959). Desde este momento, cualquier intento por llevar a la gran pantalla la historia del Holocausto ha contado con detractores. "No ha habido ningún intento de relatar el exterminio nazi de los judíos europeos que no haya producido - con las debidas variaciones - su polémica correspondiente" (Arias Maldonado, 2016).

La crisis persistió y se analizaba con lupa cualquier texto fílmico estrenado. La tendencia cambió en 1985, año en el que Claude Lanzmann presentó Shoah, un documental de nueve horas de duración en el que su autor había trabajado durante los últimos once años, visitando una quincena de países y almacenando más de 350 horas de grabaciones. El filme se compone de entrevistas con tres tipos de personajes: 
las víctimas que sobrevivieron, los testigos presenciales de lo que allí aconteció y los verdugos. Están rodadas, mayoritariamente, en los antiguos campos de exterminio tal y como permanecen en el momento en que se rueda el documental. A estos paisajes los denominó Lanzmann "non-lieux de la memoire": "lugares vacíos y mudos a los que hay que hacer hablar al ritmo de los testimonios" (Sánchez-Biosca, 2006: 124). En su ingente y documental trabajo, que algunos críticos han calificado de "monumento"3, el director francés rueda sin conceder nada a la invención, ni siquiera a la imagen de archivo, y cede el absoluto y total protagonismo al testimonio oral de los supervivientes: "Es una especie de oxímoron, pues es una extraordinaria narración testimonial de lo que allí aconteció, pero en la que se preserva el misterio de un acontecimiento que Lanzmann califica de inabarcable y obsceno si se pretende explicar" (Mendieta, 2016: 167). Esta forma tan próxima a la irrepresentabilidad del Holocausto tuvo sus seguidores inmediatos, por lo que Lanzmann se erigió como guardián de la correcta representación del Endlösung (Solución final). Pero, especialmente, tuvo sus detractores.

Fue el propio Lanzmann el primer encargado de avivar la polémica y dotarle un cariz universal tras el estreno en Francia de La lista de Schindler (Schindler's List, 1993). Para este, la cinta de Spielberg era un ejemplo de la banalización y la trivialización que la ficción puede dotar al Holocausto: "Spielberg ne peut pas raconter l'histoire de Schindler sans dire aussi ce qu'a été l'Holocauste; et comment peut-il dire ce qu'a été l'Holocauste en racontant l'histoire d'un Allemand qui a sauvé 1300 juifs, puisque la majorité écrasante des juifs n'a pas été sauvée?"' (Lanzmann, 1994). Por esta razón, y por apelar indiscriminadamente a alterar los sentimientos del espectador, Lanzmann afianzó aún más su postura y explicó que la única forma válida de representar la barbarie era como él lo había hecho varios años atrás, con total omisión de la imagen de archivo y el privilegio de la palabra del testigo, en un claro intento de hallar la verdad. "Las imágenes de Shoah recorren los lugares con el fin de crear huella de lo que no ha dejado huella y en este sentido no puede confiar en ninguna imagen de archivo previa, sino que, antes bien, constata su falta de valor testimonial" (Sánchez-Biosca, 2006: 94). Se trata, por lo tanto, de exigir un total pudor en lo que se representa, y eso es algo que solo se consigue con la oralidad de los testimonios.

Las declaraciones tan tajantes de Lanzmann y la egolatría de la que hacía gala respecto a su trabajo ${ }^{5}$ recibieron rápidamente el rechazo de infinidad de autores. Uno de los primeros en oponerse a la visión de Lanzmann y sus seguidores fue Jorge Semprún. El escritor español, que estuvo internado durante un año y medio

3 Es el caso de Imanol Zumalde, Carmen Arocena y Santos Zunzunegui, que en su artículo "Imágenes del otro: el cine en la comprensión de la discriminación”, aseguran que tanto Shoah, como el resto de sus películas sobre el Holocausto, constituyen un "monumento en el que el mármol ha sido sustituido por el celuloide" (Zumalde, Arocena, Zunzunegui, 2010: 93).

4 "Spielberg no puede contar la historia de Schindler sin decir también qué fue el Holocausto; y ¿cómo puede el decir qué fue el Holocausto contando la historia de un alemán que salvó a 1300 judíos, cuando la abrumadora mayoría de judíos no fueron salvados?". Traducción propia.

5 Aunque Shoah es la gran obra de Lanzmann, también rodó otros filmes sobre el Holocausto: Alguien vivo pasa (Un vivant qui passe, 1997), Sobibor, 14 de octubre de 1943, 16h. (Sobibór, 14 octobre 1943, 16 heures , 2001), The Karski Report (Le rapport Karski, 2010) y El último de los injustos (Le dernier des injustes, 2013). 
en Buchenwald, habló sin tapujos del poder catártico de la ficción en sus libros y, especialmente, en su gran obra La escritura o la vida (1995):

¿Pero se puede contar?, ¿Podrá contarse alguna vez? [...] Solo alcanzarán esta sustancia, esta densidad transparente, aquellos que sepan convertir su testimonio en un objeto artístico, en un espacio de creación. O de recreación. Únicamente el artificio de un relato dominado conseguirá transmitir parcialmente la verdad del testimonio (Semprún, 1997: 25).

Para el superviviente español, rebasar la evidencia del horror por medio de la narración es la única forma de poder superar el "mal radical" y transcenderlo. Por esto, en las líneas del ensayo insiste en la idea de sacar a relucir el "artificio": "Contar bien significa: de manera que se sea escuchado. No lo conseguiremos sin algo de artificio. ¡El artificio suficiente para que se vuelva arte!” (Semprún, 1997: 140). Un modo de entender la representación y transmisión del horror muy lejano al admitido por Lanzmann, que rechaza, como se ha dicho, cualquier atisbo de énfasis ficcional. Semprún lleva hasta las últimas consecuencias su idea, como demuestra el lenguaje de La escritura o la vida: "Jamás podré contemplar las figuras de Giacometti sin acordarme de los extraños paseantes de Buchenwald: cadáveres ambulantes en la penumbra azulada del barracón de los contagiosos" (Semprún, 1997: 58). En 2003, y con motivo de unas jornadas celebradas en la Residencia de Estudiantes y organizadas por esta institución y el Instituto de Filosofía del CSIC, dentro de las XII Conferencias Aranguren de Filosofía, Semprún ofreció un trío de conferencias tituladas Kant y la mochila del maquis, El mal radical y las letrinas de Buchenwald y Literatura y memoria del mal: de Sartre a Paul Ricoeur - en el que sí arremetió contra la postura tan tajante de Lanzmann de no considerar la ficción como vía viable para comprender la barbarie. ${ }^{6}$

Mayor fue aún la crisis de la representación de la imagen tras la publicación de Imágenes pese a todo, que provocó la respuesta contrariada de Gerard Wajcman y Elisabeth Pagnoux en artículos escritos, precisamente, en Les Temps Modernes, la revista dirigida por Lanzmann. El ensayo de Didi-Huberman es, desde su inicio, una declaración de intenciones del poder que le otorga a las imágenes como medio para tratar de comprender el mal: "Para saber hay que imaginarse" (Didi-Huberman, 2004: 17). En este realiza un análisis de las cuatro fotografías tomadas, presuntamente, por Alberto Errera - Alex - un judío griego que se hizo con una cámara y que tomó cuatro imágenes en agosto de 1944 en Auschwitz-Birkenau ${ }^{7}$; dos de ellas dentro de la cámara de gas, en las que se ve a distintos miembros del sonderkommando mientras recogen una pila de cadáveres; y otras dos tomadas en algún punto de ese infierno, en pleno bosque, y en el que se puede ver a distintas mujeres momentos antes de entrar en una cámara de gas. "Gracias a estas imágenes, disponemos, pese a todo, de una representación que, desde ese momento, se impone como la representación por excelencia, la representación necesaria de lo que fue un momento del mes de agosto de 1944 en el crematorio V de Auschwitz" (Didi-Huberman, 2004: 66).

6 Previamente, en mayo de 2000, Semprún había publicado L'art contre l'oubli, en Le monde des debats, pp.1113. En este, el exmilitante comunista calificó la visión del director francés de "extrema y fundamentalista".

7 Al parecer, un miembro de la resistencia polaca habría introducido la cámara de fotos en el campo de exterminio, según explica Didi-Huberman en Imágenes pese a todo. 
El pese a todo es clave en la lectura que de estas imágenes hizo el historiador de arte francés, pues estas fotografías, aunque fragmentadas y parciales, refutaban lo inimaginable, que era lo que querían conseguir los nazis al tratar, sin éxito, de borrar todas las huellas de lo que aconteció en Auschwitz. Para este, estos cuatro fragmentos son "más preciosos y menos sosegadores que todas las obras de arte posibles, arrebatados como fueron a un mundo que los deseaba imposibles. Así pues, pese a todo, imágenes: pese al infierno de Auschwitz, pese a los riesgos corridos" (Didi-Huberman, 2004: 17).

Asimismo, Didi-Huberman defendió las cuatro capturas como "instantes de verdad", tal cual lo definió Hannah Arendt en su obra Le procès d'Auschwitz: "esos instantes son de hecho todo aquello de lo que disponemos para poner orden en este caos del horror" (Didi-Huberman, 2004: 57). Todo lo contrario opinó Lanzmann, para el que estas cuatro imágenes no tenían ninguna valía. Antes de la publicación de Imágenes pese a todo, Didi-Huberman ya había defendido la importancia de estas cuatro imágenes capturadas por Alex en el catálogo de una exposición sobre el Holocausto celebrada en París en el año 2000. Lanzmann, ante esta lectura de Didi-Huberman que luego desarrollará por escrito, se mostró disconforme en una entrevista en Le Monde: "Ces quatre photos sont enfin longuement analysées par Georges Didi-Huberman, qui se prend à les fétichiser, avec l'intention obscure de nous faire croire que nous disposons de photos de ce qui se passe à l'intérieur d'une chambre à gaz pendant l'opération de gazage. On les attend encoré"9 (Guerrin, 2001).

Elisabeth Pagnoux y Gerard Wajcman, por tanto, continuaban la línea marcada por Lanzmann en estas declaraciones. "Para estos autores los límites de la representación son radicales, ontológicos, es imposible para cualquier conciencia voluntaria ver o imaginar el Holocausto, e intentarlo significa una afrenta moral imposible de remontar" (Burucúa y Kwiatkowski, 2015: 19). Tanto Wajcman como Pagnoux aseguraban que no existían imágenes de la Shoah y que, en todo caso, las imágenes mentían al realizar Didi-Huberman un ejercicio de sobreinterpretación. En su impertérrita defensa del testimonio, Wajcman no dudó en descalificar la imagen de archivo: "La idea del documento visual sobre la Shoah se considera fuera de juego" (Wajcman, 2001: 240).

En este contexto, Didi-Huberman aprovecha la publicación de Imágenes pese a todo para desarrollar en profundidad el argumento a favor de las imágenes de Alex - como ya había hecho en el catálogo de la exposición - y, además, contesta a las acusaciones de Lanzmann, Wajcman y Pagnoux en la segunda parte del ensayo, que denomina Pese a la imagen toda. Lo primero que realiza el autor es defender el póker de fotografías como medio válido para tratar de comprender, pues asegura que las imágenes suponen un punto de contacto irrefutable con lo real. "Ante las cuatro fotografias de Auschwitz, simplemente he tratado de ver para saber mejor. ¿Qué puedo responder a aquellos que se enfurecen ante el principio mismo de tal tentativa?" (Didi-Huberman, 2004: 90). En segundo término, contesta a Wajcman y Pagnoux con la evidencia de que, a diferencia de lo que ellos alegaban, el Holocausto no es ni inimaginable ni irrepresentable, pues si ha ocurrido es que pudo ser imaginado

8 Didi-Huberman cita en su texto Le procès d'Auschwitz (Arendt: 257-258).

9 Lanzmann: "Estas cuatro fotografías son analizadas extensamente por Didi-Huberman, que las pretende fetichizar, con la oscura intención de hacernos creer que tenemos fotos de lo que ocurre dentro de las cámaras de gas durante la operación de gaseado. Le estamos esperando aún”. Traducción propia. 
y se puede representar: “¿Cómo va a ser impensable si fue pensado?, ¿cómo va a ser indecible e irrepresentable si ha sido dicho, contado y representado mil veces? Para Didi-Huberman, el horror puede y debe imaginarse y las fotografías, de hecho, ayudan" (Sáez de Urabaín, 2015: 239). En última instancia, y con una facilidad pasmosa, refuta la afirmación de Wajcman de que el Holocausto permanece sin imágenes. Para ello, se remite a las cuatro fotografías objeto de estudio y, además, le recuerda que los propios nazis tomaron infinidad de instantáneas, aunque la mayoría de ellas fueron destruidas en su desesperado intento por no dejar rastro del horror: "La administración nazi tenía tan fijadas sus rutinas de registro — su soberbia, su particular narcisismo burocrático - que tendía a consignar y a fotografiar todo lo que se hacía en el campo, aunque el gaseado de los judíos siguió siendo 'secreto de Estado" (Didi-Huberman, 2004: 45). Además, el historiador francés recuerda, a modo de ejemplo, la gran cantidad de iconografía médica generada por Josef Mengele en sus monstruosos experimentos.

En Imágenes pese a todo, por lo tanto, Didi-Huberman pretende avisar a sus tres contendientes de la fuerza poderosa de la imagen fotográfica como captadora de verdad — en especial a Pagnoux, que acusaba a la imagen de mentir- Es por eso que el historiador francés parece tener en mente las ideas que el semiólogo Roland Barthes había desarrollado en su ensayo La cámara lucida acerca del peso real de lo capturado por el objetivo: "La fotografía jamás miente, o mejor, puede mentir sobre el sentido de la cosa, siendo tendenciosa por naturaleza, pero jamás podrá mentir sobre su existencia" (Barthes, 2011: 99).

El debate prosiguió y se acentuó con la aparición de los diversos textos fílmicos o artísticos que trataron el Holocausto. Incluso, diversos intelectuales trataron de explicar que el debate estaba ya vacío, y que se dirigía a la forma en que se representaba. Así lo manifestó Jacques Rancière en una conferencia a la que tituló El viraje ético de la estética y la política: "El problema no es saber si se puede o se debe o no representar, sino qué se quiere representar y qué modo de representación se elige para este fin" (Rancière, 2005). Para él, por tanto, ya no tiene sentido hablar de irrepresentabilidad en el sentido que lo habían hecho Lanzmann, Wajcman y Pagnoux, sino que el Holocausto, como fenómeno o suceso existente, cuenta con un lenguaje y una sintaxis para poder ser representado por medio del arte. "Sugiere así Rancière que el reproche de la irrepresentabilidad nace de una insatisfacción en apariencia irremediable: el anhelo por un arte distinto, capaz de expresar lo radicalmente distinto" (Arias Maldonado, 2016).

Por consiguiente, parece evidente que es un debate que parece no tener fin. Siempre que un estreno sobre el Holocausto llega a las carteleras nacionales no son pocos los que se atreven a realizar una lectura sobre lo conveniente de su representación, y que se dedican a analizar cómo la propuesta muestra el horror desde planteamientos éticos y estéticos. Con El hijo de Saúl ocurrió lo mismo, pero a diferencia del filmes anteriores, y he aquí el hito, esta película consiguió cosechar interpretaciones positivas de ambos bandos.

\section{El hijo de Saúl: un monstruo necesario}

Un novel director de 37 años, perteneciente a la cuarta generación tras Auschwitz su bisabuelo había fallecido en este campo de exterminio-, volvió a reabrir la crisis 
de la representación de la imagen del Holocausto con un texto fílmico potentísimo, que generó rápidas lecturas y críticas, generalmente positivas, desde su presentación en la sección oficial del Festival de Cannes de $2015^{10}$. Especialmente, fue alabada por lo arriesgado y original de su planteamiento estético, anteriormente no visto en una ficción de esta temática.

El filme se centra en Saúl Aüslander, un judío húngaro que es miembro del sonderkommando de Auschwitz. En la habitual recogida de cadáveres, Saúl descubre que un niño ha salido con un último aliento de vida de la cámara de gas, y observa cómo un médico nazi se encarga de ahogarlo del todo. Tras esto, el objetivo del protagonista va a ser tratar de dar una sepultura justa al muchacho bajo el rito hebreo, y para ello explica a todos que el niño es su hijo. Se trata de "la posibilidad de sentirse humano en medio de la deshumanización más atroz y hacer que un niño siga existiendo aunque ya esté muerto" (Heredero, 2016: 11). Por eso, el único propósito de Saúl es el de hallar en el caos de la barbarie a un rabino que pueda oficiar el tradicional rezo fúnebre hebreo por el muchacho. Algo que nunca conseguirá, y que concluye con el cadáver del niño arrastrado por la corriente del río Vístula, tras un fallido intento de rebelión de varios miembros del sonderkommando, que acabará con la muerte de todos ellos por disparo de los SS.

No era el primer acercamiento de Nemes, pese a su juventud, al Holocausto. Once años atrás, cuando ejercía como ayudante del cineasta húngaro Béla Tarr, había rodado el cortometraje Türelem, ${ }^{11}$ centrado en el punto de vista de una joven funcionaria encargada de realizar diversas tareas burocráticas en un campo de concentración, y que fue rodado en un único plano-secuencia. Al final de este cortometraje, se mostraba un verde prado en el que, previamente, diversos miembros del sonderkommando desnudaban a otros prisioneros para enviarlos a las cámaras de gas. Justamente, El hijo de Saúl se inició en un bosque de excelso verdor tras el que aparece Saúl, por lo que este inicio funciona como "metafórica continuación de su primer corto" (Heredero, 2016: 10). Desde ese momento, la cámara no abandonará al protagonista durante la práctica hora y media en que se prolonga el filme, por lo que Nemes pretende que el único punto de vista sea el de Saúl, y que el espectador observe lo mismo que este observa, por lo que el cineasta realiza una inmersión total y eficaz.

Por tanto, el hecho de que esta cinta reabra el debate intelectual, moral y filosófico sobre la representación de la imagen se debe a lo novedoso de su puesta en escena. Así, toma sentido la pregunta que se hace Violeta Kovacsics ante lo original del planteamiento estético y ético de Nemes: "cómo filmar después de Auschwitz" (Kovacsics, 2016: 14). Justo la pregunta que había seguido a cualquier aparición de un texto fílmico novedoso, sin olvidar Noche y niebla (Nuit et brouillard, 1955), de Alain Resnais, Shoah, de Claude Lanzmann o la propia Lista de Schindler, en 1993, pese a la práctica unanimidad en criticarla por su banalización de la tragedia ${ }^{12}$.

10 En el presente artículo, y dado que lo que aquí interesa es la forma en que se representa la imagen, las críticas analizadas sobre El hijo de Saúl son siempre positivas. El filme obtuvo mucho más elogios que comentarios negativos, pero también es justo reseñar que no fue algo unánime. Stefan Grissemann, en la prestigiosa revista Film Comment, aseveró que el trabajo de Nemes no se correspondía a la historia y que era intelectualmente repelente.

11 Disponible en Youtube: https://www.youtube.com/watch?v=5g1FIkw9CYM

12 Incluso el propio Didi-Huberman, que se mostró vehemente a favor de la ficción, criticó en Imágenes pese 
El primero en reaccionar de manera entusiasta al estreno de la cinta fue Georges Didi-Huberman quién, incluso, envió una carta a László Nemes, que se convertiría en el libro Sortir du noir ${ }^{13}$ (2016). El contenido íntegro de la misiva es completamente halagador con el joven director desde el propio inicio: "Votre film, Le Fils de Saul, est un monstre. Un monstre nécessaire, cohérent, bénéfique, innocent. Le résultat d'un pari esthétique et narratif extraordinairement risqué ${ }^{14 "}$ (Didi-Huberman, 2016: 7). En esta, Didi-Huberman no deja al margen el debate sobre la crisis de la representación reabierto por la película, y felicita a Nemes por haber tenido en cuenta las fotografías tomadas por Alex:

Vous parlez alors -et c'est parfaitement cohérent avec votre lecture des manuscrits enfouis- des quatre photographies réalisées en aout 1944 par les membres du Sonderkommando du Crématoire $\mathrm{V}$ de Birkenau. Vous dites que ces images vous ont 'enormement marqué, parce que, précisez vous, elles posent des questions essentielles. Je suis bien d'accord avec vous, ayant tenté, il y a une quinzaine d'années de formuler certaines de ces questions. Un homme d'images tel que vous no peut pas ne pas avoir été sensible a la piussance -mais, justement, si fragile- de ces photographies ${ }^{15}$. (Didi-Huberman, 2016: 11-12).

En Imágenes pese a todo, el historiador de arte ya había escrito que las fotografías permiten "comprender la condición de urgencia en la que fueron arrebatados cuatro fragmentos al infierno de Auschwitz" (Didi-Huberman, 2004: 65). En su película, Nemes retrata fantásticamente el momento de "urgencia" que padece el sonderkommando en el momento en que este realiza las fotografías dentro de la cámara de gas. Es esta la razón por la que Didi-Huberman felicita al cineasta por haber recreado este momento. Si bien, el propio Nemes señaló en una entrevista que las fotografías que se toman en el filme "no tendrían por qué ser las mismas del libro de Didi-Huberman" (Pena, 2016: 6), aunque sí reconoció que fueron elementos históricos decisivos.

El gran triunfo para Didi-Huberman desde la óptica de la controversia de la representación o no representación de la imagen es que El hijo de Saúl demuestra, según el historiador de arte francés, lo que nunca quisieron comprender Lanzmann, Wajcman o Pagnoux, que las imágenes de archivo, como las tomadas por Alex, tienen la capacidad de salir de la oscuridad, de dar un testimonio de la luz: "L'acte photographique par excellence, pour rendre invisible et, donc, incroyable aux yeux du monde"16 (Didi-Huberman, 2016: 18).

a todo la trivialización del mal que realiza Spielberg en alguna escena de la película citada: "la nauseabunda secuencia de las duchas en La lista de Schindler" (Didi-Huberman, 2004: 112).

13 Salir de la oscuridad. Traducción propia.

14 "Su película, El hijo de Saúl, es un monstruo. Un monstruo necesario, coherente, benéfico e inocente. El resultado de una creación estética y narrativa extraordinariamente arriesgada". Traducción propia.

15 "Usted hablaba -y es perfectamente coherente con su lectura de los manuscritos enterrados- de las cuatro fotografías tomadas en agosto de 1944 por los miembros del Sonderkommando del Crematorio V de Birkenau. Usted dice que esas imágenes le han "marcado enormemente" porque, usted precisa, "plantean preguntas esenciales". Estoy bastante de acuerdo con usted, ya que hace quince años traté formular algunas de esas preguntas. Un hombre de imágenes como usted no puede haber sido insensible al poder -a la par tan frágil- de esas fotografías". Traducción propia.

16 "El acto fotográfico por excelencia, hacer visible para todos lo que los nazis querían volver del todo invisible y, por tanto, increíble a los ojos del mundo". Traducción propia. 
Se observa de este modo que, aunque la carta a Nemes sea totalmente elogiosa, Didi-Huberman aprovecha para resucitar su opinión sobre la representación de la imagen del Holocausto, y vuelve a explicar la importancia de tener en cuenta las imágenes de archivo y la ficción, como hiciera en su ensayo de 2003, pero, ahora, basándose en el ejemplo dado por El hijo de Saúl. Al final de su texto, se llega a preguntar, incluso, si Nemes ha hecho un gran hallazgo: "Auriez-vous donc inventé au cinéma le genre du 'conte documentaire'? ${ }^{17 "}$ (Didi-Huberman, 2016: 49).

Lo que resultó realmente sorprendente fueron las amables palabras que Claude Lanzmann dedicó a Nemes tras ver El hijo de Saúl en Cannes. Aparte de a su propia obra, era la primera vez que el director francés expresaba palabras realmente positivas sobre el trabajo de otro autor que se haya decidido a contar la Shoah:

A diferencia de la falacia que presentó Spielberg, que no reflexionó suficiente sobre la cuestión,
Nemes nunca muestra las cámaras de gas. No ha querido representar el Holocausto, sino la vida de
los sonderkommando. En su película, la gente corre sin descanso, entre gritos constantes de fondo.
La nobleza de Nemes consiste en no haber querido seducirnos. Al revés: la suya es una película
muy tosca (Vicente, 2016).

El director de El último de los injustos sustenta su comentario favorable a la forma en que el trabajo de Nemes representa el horror en su cercanía al ascetismo visual y en su presunta intención de no contar la barbarie en su plenitud, sino de acercarse a la particular historia de un integrante del sonderkommando. Curiosamente, Lanzmann no parece mostrar objeción en que se usen como elemento en la película imágenes de archivo - algo que él y sus seguidores tanto habían criticado- ni tampoco enjuicia que el filme sea una ficción. La lectura positiva sobre la cinta de Nemes resultó inesperada en un creador que, hasta el estreno de esta cinta, solo había defendido como válida para mostrar el Holocausto su propia obra fílmica.

De este modo, el director húngaro recibió elogios por la forma de representar la Shoah de los dos estandartes de ambas posiciones históricamente enfrentadas. Eso sí, pese a reconocer estar al tanto de la histórica crisis, explicó que esta no le concernía a él: "No se trataba de seguir esa polémica y proponer una respuesta. Quería hacer una película a partir de un único personaje, pegándome a él, pero sabiendo que no podía mostrar aquello que el cine suele mostrar en estos casos" (Pena, 2016: 7).

Al margen de que Nemes pretenda mantener una inteligente distancia con la polémica, lo evidente es que su forma de representar el Holocausto en su película es original y diferente respecto a lo que se había rodado hasta la fecha sobre esta temática. Por esta razón, es necesario analizar el planteamiento ético y estético de la cinta para comprender cómo Nemes se acerca a la representación de la imagen de la barbarie. La primera característica reseñable es que adopta durante la totalidad del metraje un único punto de vista, que es el del propio Saúl Aüslander. El cineasta acompaña al protagonista sin abandonarlo en ningún momento, por lo que el espectador observa lo mismo que el personaje de ficción, lo que genera que la inmersión en el horror de Auschwitz sea total. Abundan, por tanto, los primeros planos del rostro de Saúl, que se muestra carente de emoción e inexpresivo, como los "modelos" de los filmes de Robert Bresson. Esta elección estética provoca una de las grandes novedades en la puesta de escena del filme: todo lo que rodea al personaje, el ambiente en el que 
se mueve, se filma pretendidamente borroso, por lo que la profundidad de campo es ínfima. Así lo observa Didi-Huberman: "Vous etes parti de cette évidence que, dans un tel espace où l'horreur est obsidionale, le suel regard possible est un regard de courte distance et de courte durée: un regard contraint de traverser la mort en passant, pues de vite baisser les yeux vers le sol" (Didi-Huberman, 2016: 29) ${ }^{18}$. Es por eso que, en Sortir du noir, el filósofo francés califica los fotogramas de imágenes-pánico.

La segunda característica reseñable del modo de representar la imagen del filme de Nemes emana directamente de la segunda. La elección de los primeros planos constantes y la limitación de la profundidad de campo provocan que lo visual se diluya en detrimento de lo sonoro. El hijo de Saúl es una auténtica vorágine sonora, compuesta de diálogos irreconocibles en alemán o húngaro, gritos que se mezclan entre las órdenes de los verdugos y los alaridos de las víctimas, alientos entrecortados y un caos de sonidos difícil de reconocer que podrían pasar por conformar la banda sonora del infierno. Así, imagen y sonido parecen enfrentarse en un filme impuro y ruidoso. Todo esto acrecienta la experiencia sensorial, la proximidad de la verdad, como buscaba Lanzmann. "En este terreno, sensacional y afectivo, El hijo de Saúl cumple con creces su función representativa sin dejar por ello de trascender - como experiencia cinematográfica particular - esa misma función" (Arias Maldonado, 2016).

Como tercer rasgo destacado para analizar su representación se ha de señalar el inteligente juego que Nemes realiza entre silencio y lenguaje. Pese al incesante ruido reseñado en el que se sume toda la película, aparecen instantáneos - pero muy reveladores - momentos de silencio. Es el caso del final, cuando aparece la única risa en Saúl tras observar al niño polaco que aparece ante él. Sin duda, el silencio que precede a la muerte. Pero la palabra también es usada con eficacia. El protagonista habla poco, apenas nada, pero sus sentencias son absolutamente eficaces para confeccionar una imagen del infierno en que se halla. Mientras los miembros del sonderkommando preparan una rebelión, Saúl le dice a un compañero: "Ya estamos muertos". Algo que recuerda a pasajes de las memorias de Semprún en La escritura o la vida: "Ninguno de nosotros, jamás, se habría atrevido a soñar algo así. Ninguno había estado lo suficientemente vivo como para soñar incluso, para arriesgarse a imaginar un porvenir" (Semprún, 1997: 22).

Es Saúl, por tanto, un héroe muy difícil de comprender. Su única meta en el campo de exterminio no es sobrevivir, porque como expresa él, ya está muerto, por lo que el único gesto que lo ata a la vida es el de poder brindarle el entierro al niño. Este hecho evoca como intertexto la obra Kaddish por un hijo no nacido, de Imre Kertész, quien sí sobrevivió a Auschwitz y Buchenwald. El autor húngaro no consiguió ser padre tras el Holocausto, pero sí escribir. Kertész buscó dar una respuesta a la barbarie desde la literatura, al igual que Nemes lo propone desde el cine. “'¡No!', nunca podré ser padre, destino, dios de otra persona, '¡no!', nunca podrá ocurrirle a otro niño lo que me ocurrió, la infancia, '¡no!', gritaba, vociferaba algo en mí, es imposible que eso, la infancia, le ocurra - te ocurra - me ocurra” (Kertész, 2001: 112).

Con la muerte del protagonista — de nuevo no mostrada, pero sí escuchada-, Nemes pone punto y final a su película. Saúl no sobrevive, por lo que la verdadera

18 "Usted comparte la certeza de que, es un espacio donde el horror es claustrofóbico, la única mirada posible es una mirada de corta distancia y de corta duración: una mirada forzada a toparse con la muerte al pasar, y después bajar rápidamente los ojos al suelo". Traducción propia. 
triunfadora es la imagen: "L'ombre et la lumière, le noir et le blanc, le net et le flou témoignent directement de la situation dont ces images apparaissent comme les 'survivantes""19 (Didi-Huberman, 2016: 13). Es evidente que la originalidad del planteamiento estético escogido por Nemes es muy respetuosa con la información histórica que contiene, y que compone una inmersión auténtica en el horror sin artificios ni trivialización de lo mostrado, en pos de un pretendido acercamiento a la verdad, por lo que se puede entender por qué su cinta es respetada por Lanzmann. Pero también usa fotografías de archivo, y privilegia el poder de la imagen con una historia ficcional, en la que se vale de muy distintos registros cinematográficos, por lo que es comprensible que también guste a Didi-Huberman y los defensores de sus postulados. Por estas razones, El hijo de Saúl es todo un hito: ha conseguido plantear una forma de representar la imagen de la Shoah totalmente original, distinta a lo filmado hasta entonces y que genera fructíferas lecturas de las dos partes históricamente enfrentadas en esta controversia.

\section{Conclusiones}

La reapertura de un debate de cariz moral, filosófico, cultural y, evidentemente, cinematográfico es siempre positivo si la propuesta que vuelve a generar las lecturas es tan rica en ellas como El hijo de Saúl. Hasta su estreno, era difícil imaginar que las dos corrientes, que habían defendido postulados tan distintos, pudieran estar de acuerdo en alabar la calidad de un mismo producto cinematográfico. Era previsible en la posición encabezada por Didi-Huberman, pues siempre había privilegiado el uso de las imágenes y la ficción como vías para representar la Shoah. No es que todo valiese a la hora de mostrar — pues, como se ha dicho, el propio historiador de arte criticó duramente la banalización a la que, según su juicio, se exponían diversas secuencias de La lista de Schindler-, sino que se trataba de aspirar a un merecido respeto y un intento de autenticidad en los diversos textos fílmicos aparecidos. Como expone Fernández López “es lícito que las representaciones sobre el Holocausto sean leídas no solo como información histórica o posicionamiento ético, sino también interrogadas acerca de su características formales y estéticas" (Fernández López, 2006: 10). El respeto, desde el planteamiento moral y estético, ha de ser obligatorio en cualquier texto fílmico que se precie, ya sea cercano al documental o una completa ficción. Por esto, Elie Wiesel se molestó tanto ante la banalización que se daba en las imágenes de la serie Holocausto (Holocaust, 1978) ${ }^{20}$, de Gerald Green. Wiesel, en un duro escrito en The New York Times, resumió que el Holocausto sí que debía ser recordado, pero nunca bajo el formato de serie de televisión: "Listen to the survivors and respect their wounded sensibility. Open yourselves to their scarred memory, and mingle your tears with theirs. And stop insulting the dead"21.

El daño a las víctimas de la barbarie era lo que argüía Lanzmann para erigirse en guardián de la correcta representación de la imagen del horror y considerar su

19 "La sombra o la luz, el negro o el blanco, lo definido y lo borroso son testimonio directo de la situación en que esas imágenes aparecen como las 'supervivientes"”. Traducción propia.

20 Holocausto fue una miniserie de televisión dirigida por Gerald Green, en 1978, compuesta por seis capítulos.

21 "Escuchen a los heridos y respeten su sensibilidad dañada. Ábranse a su memoria herida, y mezclen sus lágrimas con las de ellos. Y paren de insultar a la muerte". Traducción propia. 
trabajo como el único válido para tal fin, por su auténtica recreación del dolor por medio del acercamiento a la verdad y la memoria. Por eso, resultó estimulante que dedicase palabras de admiración a El hijo de Saúl. Hasta el estreno de este filme en Cannes, el director galo había rechazado el uso de imágenes históricas, la existencia de narradores externos, la dramatización actoral en pos de provocar emociones o la narrativa cronológica. Es, precisamente, lo innovador de la propuesta de Nemes lo que pareció seducir a Lanzmann, así como su respetuoso acercamiento a la verdad. De hecho, en este último punto, Nemes reconoce que el filme partió de unos diarios desenterrados en Auschwitz a los que él había podido acceder varios años atrás. Además, no existe un narrador, pues la única focalización recae en la mirada de Saúl, y el rostro es pretendidamente inexpresivo, más propio de un espectro fantasmal que linda con la muerte que el de un actor. Sin duda, en El hijo de Saúl aparecen una serie de imágenes pre-verbales que tienen la capacidad de accionar la memoria, como ocurría en los testimonios de Shoah, y por esto resulta comprensible que le interesase a Lanzmann.

Pero lo absolutamente revelador y destacado de esta cinta es la apuesta formal y estética tan original que plantea Nemes, en un juego cinematográfico que bascula entre la realidad y el mundo de las pesadillas. La cámara se mueve al mismo tiempo que lo hace el protagonista, con el claro objetivo de concebir el miedo y causar una experiencia sensorial al espectador absoluta, en la que destacan los primeros planos del prisionero. Todo lo restante queda fuera de foco, con una profundidad de campo escasa. Esto genera una cierta tactilidad con el espectador. De hecho, es tan eficaz la inmersión que se recorre el averno junto con el personaje, por lo que pasa a "formar parte de la serie histórica de descripciones infernales explícitas acometidas por Dante, El Bosco, Beccafumi, Rubens, Milton, y de las metáforas de Joseph Conrad, Francis Ford Coppola o las novelas de caucherías" (Burucúa, 2016). Esta forma de rodar provoca que la ficción y la objetividad se coimpliquen, y que en el filme resida cierta precisión documental.

Por tanto, la crisis reabierta por la llegada de El hijo de Saúl lleva el debate a nuevos parámetros, dada la originalidad de la propuesta filmada por Nemes. Al igual que ha sucedido ante cualquier estreno de un producto aceptado como de calidad, como ocurrió con Noche y niebla o con Shoah, esta película ha suscitado interpretaciones y lecturas de muy variada dirección sobre la forma en que se representa la imagen. Esto, dentro de los principios del respeto y de la deferencia ética y estética antes citada, deviene en reflexiones históricas, filosóficas y cinematográficas muy ricas para la investigación.

Este texto surge dentro del marco del Proyecto de Investigación UCM-Santander. Referencia: PR26/16-6B-1, titulado: PERLAD, Pensamiento y representación literaria y artística digital ante la crisis de Europa y el Mediterráneo. 


\section{Bibliografía}

Arias Maldonado, M. (2016). "No es mejor callar. Auschwitzy los límites de la representación”. Nueva Revista de cultura, política y arte, $\mathrm{n}^{\mathrm{o}}$ 156, enero de 2016. Recuperado de http:// www.nuevarevista.net/articulos/no-es-mejor-callar-auschwitz-y-los-limites-de-larepresentacion (Fecha de acceso: 07/12/2017).

Barthes, R. (2001). La cámara lúcida. Barcelona: Paidós.

Burucúa, J. E. (2016). “Cómo describir lo indescriptible”. El País, enero de 2016. Recuperado de https://elpais.com/cultura/2016/01/08/actualidad/1452252338_122449.html Fecha de acceso: (08/12/2017).

Burucúa, J. E. y Kwiatkowski, N. (2015). 'Cómo sucedieron estas cosas'. Representar masacres y genocidios. Buenos Aires: Katz.

Didi-Huberman, G. (2004). Imágenes pese a todo. Barcelona: Paidós.

Didi-Huberman, G. (2016). Sortir du noir. París: Les Éditions de Minuit.

Fernández López, J. A. (2006). “En los límites de lo indecible. Representación artística y catástrofe". A Parte Rei. Revista de Filosofia, no 48, pp. 1-12.

Heredero, C. (2016). "La resistencia moral”. Caimán. Cuadernos de cine, no 45 (96), enero 2016, pp. 10-11.

Guerrin, M. (2001). “Claude Lanzmann, écrivant et cinéaste: ‘La question n’est pas celle du document, mais celle de la vérité' [Entrevista realizada a Claude Lanzmann]'. Le Monde, enero de 2001. Kertész, I. (2001). Kaddish por el hijo no nacido. Barcelona: Acantilado. Recuperado de http://www.lemonde.fr/archives/article/2001/01/18/claude-lanzmannecrivain-et-cineaste-la-question-n-est-pas-celle-du-document-mais-celle-de-laverite_138553_1819218.html?xtmc=lanzmann\&xtcr=6 (Fecha de acceso: 07/12/2017).

Kovacsics, V. (2016). "El arte como descendencia”. Caimán. Cuadernos de cine, no 45 (96), enero 2016, pp. 12-14.

Lanzmann, C. (1994). "Holocauste, la representation impossible". Le Monde, marzo de 1994. Declaraciones extraídas de "Rétrocontroverse: 1994, peut-on représenter la Shoah á l'écran", en Le Monde, agosto de 2007, Recuperado de: http://www.lemonde. fr/idees/article/2007/08/08/retrocontroverse-1994-peut-on-representer-la-shoah-a-1ecran_942872_3232.html (Fecha de acceso: 07/12/2017).

Levi, P. (2010). "Los hundidos y los salvados". En Trilogía de Auschwitz, Barcelona: El Aleph, pp. 475-652.

Mendieta Rodríguez, E. (2016). "El cine documental de Claude Lanzmann. El Holocausto contado a partir de Shoah". Revista de Filología Románica, vol. 33, Número Especial, pp.165-174. DOI: http://dx.doi.org/10.5209/RFRM.55869

Pena, J. (2016). “Entrevista a László Nemes. Viaje al corazón de la muerte”. Caimán. Cuadernos de cine, $\mathrm{n}^{\circ} 45$ (96), enero 2016, pp. 6-8.

Rancière, J. (2005). "El viraje ético de la estética y la política". Fractal, abril de 2005. Recuperado de http://www.mxfractal.org/JacquesRanciere.html (Fecha de acceso: 07/12/2017).

Sáez de Urabaín, A. (2015). “Puede la fotografía mostrar lo inimaginable? El debate en torno a la representación de la Shoah". Fotocinema: Revista cientifica de cine y fotografía, $\mathrm{n}^{\mathrm{o}} 10, \mathrm{pp} .233-262$.

Sánchez-Biosca, V. (2006). Cine de historia, cine de memoria. La representación y sus límites. Madrid: Cátedra.

Semprún, J. (1997). La escritura o la vida. Barcelona: Tusquets. 
Vicente, A. (2016). "Historia de una polémica". El País, enero de 2016. Recuperado de https://elpais.com/cultura/2016/01/08/actualidad/1452266477_763745.html (Fecha de acceso: 07/12/2017).

Wajcman, G. (2001). El objeto del siglo. Buenos Aires: Amorrortu.

Wiesel, E. (1989). “Art and the Holocaust: Trivializing Memory". The New York Times, junio de 1989. Recuperado de http://www.nytimes.com/1989/06/11/movies/art-and-theholocaust-trivializing-memory.html?pagewanted=all (Fecha de acceso: 08/12/2017).

Zumalde, I., Arocena, C., Zunzunegui, S. (2010). "Imágenes del otro: el cine de la comprensión de la discriminación". Enl@ce. Revista venezolana de Información, Tecnología y Conocimiento, $\mathrm{n}^{\mathrm{o}} 7$ (1), pp. 79-94. Recuperado de http://www.redalyc.org/ pdf/823/82312576006.pdf Fecha de acceso: (06/12/2017).

\subsection{Filmografía imprescindible}

Lanzmann, C. (1985). Shoah. Francia: Les Films Aleph/ Historia/ Ministère de la Culture de la Republique Française.

Nemes, L. (2015). Saul fia. Hungría: Laokoon Filmgroup. 
